\title{
Personality, Political Behavior, and Political Views about Mexico's 2012 Presidential Election
}

\author{
Personalidade, Comportamento Politico e Visões Políticas sobre a \\ Eleição Presidencial no México em 2012
}

\section{Alejandro Moreno \\ Sergio C. Wals}

\begin{abstract}
People's electoral behavior is understood as political predispositions and attitudes in specific institutional contexts. Recent scholarly work has included personality as a key explanatory factor in individual-level models of political participation. In this paper we build upon these recent efforts. We utilize the Big Five approach to assess the effects of different personality traits on people's likelihood of political engagement during the 2012 presidential election in Mexico. We focus on the effects of personality on voting in the election and on individual views about the integrity of the electoral process. We use post election survey data collected for the Comparative National Elections Project in the 2012 Mexican presidential election. Our findings show that extraversion is a critical individuallevel factor accounting for the propensity to turnout in this election as well as to encourage political discussion with family members, friends, neighbors, and co-workers.
\end{abstract}

\section{Keywords}

Mexico; Political Attitudes; Institutional Contexts.

\section{Resumo}

O comportamento eleitoral das pessoas é entendido como predisposiçóes políticas e atitudes em contextos institucionais específicos. Os recentes trabalhos acadêmicos incluem a personalidade como um fator explicativo central em modelos de nível individual de participação política. Este trabalho é desenvolvido levando em conta esses esforços recentes. Utiliza-se a abordagem Big Five para avaliar os efeitos de diferentes traços de personalidade sobre a probabilidade de engajamento político das pessoas durante a eleição presidencial de 2012 no México. O trabalho foca sobre os efeitos da personalidade no voto e em visóes individuais sobre a integridade do processo eleitoral. Utilizam-se dados da pesquisa pós-eleitoral coletados para o Projeto Nacional de Eleiçôes Comparativas na eleição presidencial mexicana de 2012. Os resultados mostram que a extroversão é um fator crítico em nível individual explicando a propensão e o comparecimento nesta eleição, bem como para incentivar a discussão política com os membros da família, amigos, vizinhos e colegas de trabalho.

\section{Palavras-chave}

México; Atitudes Políticas; Contextos Institucionais. 


\section{Introduction}

In 1950, the publication of Adorno's Authoritarian Personality (ADORNO, 1950) signified a scholarly acknowledgment in the social sciences that personality traits not only reflect political contexts but can also influence mass politics. Shortly after, Mussen and Wyszynski (1952) delved into the relationship between personality and political participation. A couple of decades later, Sniderman's (1975) work provided evidence that lower levels of self-esteem inhibited participation in the political process. In spite of these pioneering efforts, until recently, the effects of personality traits on political beliefs, attitudes, and behaviors remained largely unexplored, if not completely ignored.

Traditional models of political engagement and voting behavior have emphasized the role of individual resources, political motivations, civic duty, social pressures and connections, the information environment, and cost-benefit calculations, just to mention some of the usual explanatory factors that lead people to participate in politics or not; to vote or abstain; but personality was seldom a part of the equation ${ }^{1}$. A burgeoning body of scholarly work in political science focusing on the effects of personality on political behavior (i.e. DENNY and DOYLE, 2008; MONDAK and HALPERIN, 2008; VECCHIONE and CAPRARA, 2009; MONDAK 2010; GERBER et al. 2010 and 2011; MONDAK et al., 2010 and 2011), however, argues that paying attention to these factors alone renders an incomplete portrait of the origins of political participation (MONDAK et al., 2011). Our study joins this emerging tradition and sheds light onto our understanding about the ways in which enduring psychological differences affect political behavior. As a sizeable portion of the studies focusing on the relationship between personality traits and political behavior has been conducted using data from advanced industrial democracies (i.e. DENNY and DOYLE, 2008; VECCHIONE and CAPRARA $2009)^{2}$, we are specifically interested in assessing the impact of personality traits in the context of a new democracy, namely Mexico during the aftermath of this country's most recent presidential election in the summer of 2012.

This study focuses on the effects of personality on behavioral aspects such as turnout and political discussion, as well as on people's views about the political process. It is of particular interest here to explore the relationship between personality traits and attitudes toward non-traditional democratic means to alter the electoral

\footnotetext{
${ }^{1}$ For comprehensive studies of electoral behavior in Mexico see MORENO, 2003 and 2009.

${ }^{2}$ For remarkable exceptions, see MONDAK et al., 2010 and 2011, which use data from Uruguay and Venezuela.
} 
process. More specifically, we are interested in exploring the extent to which certain personality traits may interact with an environment where democracy is relatively new and that may produce attitudes of acceptance toward alternative means designed to affect and even obstruct the outcomes of democratic elections. This is of particular relevance in a context where the party that ruled Mexico for over 70 years, the Institutional Revolutionary Party (PRI for its initials in Spanish), was put back into power by a plurality of the popular vote. But before we move onto the analysis, it is necessary to describe in more depth our conceptualization and measures of personality.

\section{Dimensions of Personality}

Some individuals are more prone than others to accept or try ideas or practices that are strange or unfamiliar; others are more likely to engage in conversations with strangers or to offer information about themselves without requested to do so; still others are more likely to agree with people beyond their circle of immediate trust or to see things in a more critical way. And we all know that individuals tend to show different levels of maturity or emotional stability. How do we measure all these personality traits and, moreover, relate them to attitudes and behavior?

Over the past two and a half decades, the field of psychology has witnessed the emergence of the so called "Big Five" approach to measuring personality traits (i.e. GOLDBERG 1990; MCCRAE and COSTA 2003; for a comprehensive discussion of the Big Five in the study of political behavior, see MONDAK and HALPERIN, 2008). Proponents of the Big Five argue that five trait dimensions are sufficient to provide a highly comprehensive model of personality. These five dimensions are: openness to experience, conscientiousness, extraversion, agreeableness, and emotional stability. The reliability, validity, and cross-cultural applicability of the Big Five have been widely studied and documented (i.e. MCCRAE and COSTA, 1997; CHURCH, 2001; CONNOLLY et al., 2007).

Following the Big Five approach, we utilized a modified version of the TIPI (Ten-Item Personality Inventory) scale (GOSLING et al., 2003). These personality items included in our survey used ten-point bipolar scales. This is, individuals were asked to place themselves on scales from 1 to 10 where the end points represent opposite adjective-pairs associated with a particular dimension of personality. Every one of the five dimensions is measured utilizing two of these 10-point scales. For instance, in order to measure "openness to experience," individuals were asked to place themselves between 1 and 10, included, where 1 means "unimaginative" and 10 
means "imaginative." On the second scale of openness, 1 means "cautious" and 10 means "open to new experiences." Of course, individuals had the opportunity to place themselves on the end points as well as on any of the middle values of the scales. For our analyses, scales were recoded to range from 0 to 9 . The final variables were then constructed as simple additive indexes of the two corresponding scales, thus ranging from 0 to 18 , where 0 is the minimum value of the personality trait in question and 18 is the maximum possible value. Here is the list of the pair-adjectives utilized in the end points of the remaining scales: agreeableness (disagreeable/agreeable, cold/warm), extraversion (shy/sociable, quiet/extroverted), conscientiousness (careless/ dependable, disorganized/organized), and emotional stability (anxious/calm, very unstable, very stable).

Again, the five empirical dimensions of personality are constructed as scales ranging from 0 to 18 , where 0 represents the lowest and 18 the highest levels of the personality trait. The distributions are rather similar for four of these variables, showing a skewed distribution towards the higher value; the most noticeable exception is "extraversion", which actually has a more "polarized" distribution: it shows more than $20 \%$ of respondents in the lower five categories, whereas the other four variables show no more than 6\%; and it only shows $33 \%$ in the five higher values, as opposed to over $50 \%$ in the rest (actually more than $60 \%$ in three of them). The descriptive statistics confirm this: extraversion has a comparatively low mean value of 10.4 and a comparatively high standard deviation of 5.7. The mean value for the other 4 variables ranges from 13 to 14.2, and the standard deviation from 3.8 to 4.6. Apparently, the measure for extraversion differentiates individuals more distinctively.

Each of these dimensions reflects particular ways of being, enduring psychological differences, and each is expected to have differential effects on attitudes and behavior. Recent work by Mondak (2010) provides evidence of a positive relationship between openness and civic engagement. Similar results had been found when analyzing data from Uruguay and Venezuela (MONDAK et al., 2010 and 2011). Given the cross-cultural validity of the Big Five approach, we have no reason to believe that this positive relationship is any different in Mexico during the 2012 presidential election. Therefore, we expect that openness to experience should be positively correlated with our measures of turnout. Openness, also, could mitigate the conflicting aspects of political disagreement, therefore leading to an increased propensity toward political discussion.

Conscientious individuals place high value in order and responsibility, therefore they might reflect the virtues of a monitoring citizen. However, recent 
results suggest that conscientious individuals might not deem their civic duty as important as their responsibilities at work or toward their families (MONDAK, 2010). Also, conscientious individuals are expected to abide by the rules. Not surprisingly, results from a study conducted utilizing data from Uruguay and Venezuela show that conscientiousness is negatively correlated with individuals' engagement in political protest (MONDAK et al., 2011). Building upon that finding, we expect that highly conscientious individuals should be less likely to display approving attitudes toward obstructive or violent practices to alter democratic outcomes.

Extraversion should be expected to boost political discussion - shy individuals would be less likely to exchange political views with others than their more extravert counterparts. Again, recent findings from Uruguay and Venezuela show that extraversion is positively correlated with social forms of political activity such as community-level involvement as well as having worked for a political candidate. In addition, the evidence from Venezuela shows that extraversion leads to a heightened propensity of involvement in political protest (MONDAK et al., 2011). Therefore, we expect that extraversion should be positively correlated with all of our main dependent variables, namely: turnout, political discussion, and political views of integrity in the electoral process.

Regarding agreeableness, our expectations are twofold. On the one hand, one should expect agreeable individuals to fare well especially in certain types of political activity. On the other hand, given their warm and trusting nature, these individuals should be expected to display negative predispositions toward conflictive forms of participation (MONDAK et al., 2011).

Finally, we have no strong a priori expectations concerning emotional stability. We believe that this trait may serve as a filter for campaign stimuli and communications, but we are not directly testing this hypothesis on this study. Whatever the effects of emotional stability, we will be incorporating this variable in every one of our statistical models of attitudes and behavior, beginning with the role it may have in increasing or reducing turnout. But before that, let us describe our data and our model specification.

\section{Data}

We rely on the Mexican survey of the Comparative National Elections Project (CNEP), conducted in July of 2012, after the presidential election. This is a national representative sample of 1,600 registered voters based on face-to-face interviews in the respondents' households. The survey administered the core CNEP 
questionnaire and, in addition, it included the set of 10 questions described earlier: our modified version of the TIPI, making this data set one of the first ones available for the Mexican case with both measures of personality and measures of political attitudes and behaviors. The data are part of the CNEP study and are available to public access through the CNEP data archives.

\section{Dependent Variables}

Our main interest is to test the effects of personality traits on political behavior in the context of the latest presidential election in Mexico. Specifically, we are interested on the effects of personality on turnout, political discussion, and on some views about the integrity of the electoral process. Thus, we conduct several statistical analyses using the following dependent variables.

Turnout. We use a dichotomous variable derived from the self-reported question of turnout, whether the respondent voted in the most recent presidential election. In this case, $87 \%$ of respondents said they voted, which clearly is an overestimation, given that actual turnout was $67 \%$. The survey results overestimated turnout by 20 points. Because of this, we also constructed another dichotomous indicator of turnout based on a more demanding series of questions: that the respondent reported not only whether she voted in the election, but who she voted for president, for senator, and for federal deputy. The constructed indicator of turnout reduced the percent of voters in the survey to $69 \%$, which is actually closer to the official figure. A potential problem with this is that we may have left out people who actually voted but were unable to tell for whom. In any case, we conduct the same analysis for both dependent variables and test the effects of personality traits controlled for other politically relevant variables described in the section devoted to our model specification.

Political discussion. Our second set of dependent variables concerns political discussion as a form of political engagement during the latest presidential campaign in Mexico. This is another test to assess the effects of personality traits on political behavior, even if self-reported political behavior. We are specifically interested in the extent to which individual differences of personality translate into differential patterns of political discussion about the electoral campaigns, and the extent to which voters try to persuade others of their political views. The series of indicators that we use here are as follows: Convince others represents the frequency in which the respondent tries to persuade others of her political opinions and preferences. Talk to family, talk to friends, talk to neighbors, and talk to co-workers represent the frequency in which the respondent engages in political conversations with those people. All 
these variables were measured using a four-point scale, ranging from "never", "rarely", "sometimes", and "often". We also constructed an additive index of political discussion that integrates the four variables of talking about politics: the resulting scale ranges from 4 to 16 .

Views about the electoral process. Lastly, we are particularly interested in assessing the effects of personality traits on some political views. The CNEP survey is full of measures of different political opinions, many of them representing partisan or ideological sides. We looked for some that may in fact reflect particular ways of being, rather than just having an ideological content. Fortunately, the CNEP includes different views about the election process, and whether respondents believe it is acceptable or unacceptable to Obstruct campaign activities or the use of Violence to prevent a different party to access power. Both evoke almost inevitably the concept of the authoritarian personality. Our analyses, however, utilizes the Big Five approach to determine which, if any, of the five dimensions of personality influence individuals on these views about the election process.

In this section, we have described the construction of our three dependent variables. Let us now turn our attention to the construction of our independent variables. As we test the effects of personality traits on political attitudes and behaviors, we decided to control for both key demographic factors and political predispositions, which we now proceed to describe.

\section{Model Specification and Expectations}

The five dimensions of personality are the center of our explanatory model: openness to experience, conscientiousness, extraversion, agreeableness, and emotional stability. The model, however, is complemented with three demographic variables sex, age, and education - and with three variables accounting for key political predispositions - partisanship, ideology, and political engagement. Partisanship is actually a measure of the intensity of party identification, using an ordinal scale that has the following categories: non-partisans, weak partisans, and strong partisans. Because the direction of partisanship is lost in this measure, we also added dichotomous indicators of Left and Right, based on the respondents' selfclassification on a ten-point ideological scale ("Left" being those who placed themselves on points 1 thru 4, and "right" those on points 7 thru 10). Our measure of political engagement is an additive index that includes interest in the campaigns and interest in politics. We also added a measure of religiosity to the model, which is a self-reported description of how religious the respondent is. 
Our expectations for these variables are as follows. Regarding Turnout, the literature on individual resources has shown that education is positively related to voting, and that older people and men tend to be more likely to turnout on Election Day than younger people and women, respectively. A broad literature on turnout also shows that partisans and ideologues are more likely to vote, and that turnout is more common among the politically motivated or interested in politics. The evidence on religiosity is less clear, so there is no particular expectation about its role on turnout. Our expectations for the personality variables had been explained in detail earlier in the study. As a summary, though, openness and extraversion should exert the largest effects on turnout, with both of these traits displaying a positive relationship with turnout.

Turning to political discussion, theoretical expectations are rather similar. Among the five personality traits, openness to experience and extraversion both should carry the most weight on shaping individual's political discussion. In other words, one should expect a positively signed coefficient for these two constructs under the different analyzed modes of political discussion. This relationship should be particularly strong among extraverts, given that these individuals are by definition more likely to engage in discussions with others. Our expectations for the demographic variables are the same: men, older people, and more educated respondents should report more frequent discussions about politics. And expectations for political predispositions also emphasize the higher political activity of those who are more partisans, who have an ideological identification, and who are more politically motivated or engaged.

Expectations about political views are less straightforward. The acceptance of electoral malpractices such as obstruction of campaigns or the use of violence to alter the outcome of a democratic election may reflect political sides (partisanship, ideology). This effect, if present, however may be mitigated by education; but we have no clear expectation for the other demographic factors or religiosity. We do expect personality traits to influence these views in a certain direction. Openness and extraversion should play the role of boosters of acceptance of these practices, not rejection; whereas conscientiousness, agreeableness, and possibly emotional stability should hinder acceptance and promote rejection of obstruction and violence.

\section{Results}

Let us turn our attention here to the discussion of results by looking at the model of turnout, shown in Table 1, which displays results for both self-reported turnout and our constructed indicator of turnout. As expected, intensity of party 
identification and our additive index of political engagement (interest) exert a positive and significant influence on self-reported turnout, as also do sex and age. Neither the coefficient for religiosity nor those for the ideological groups on the Left or Right of the political spectrum attain any statistical significance. Among the personality traits, only extraversion shows a significant and positive effect on turnout, and emotional stability is close to the significance threshold. No other personality variable relates to turnout in a statistically significant way. In fact, in the self-reported turnout model, openness is negatively signed, which runs counter to our original expectations and past findings in the literature.

Table 1 - A model of turnout: The role of personality traits (Logistic regression)

\begin{tabular}{|c|c|c|c|c|c|c|c|c|}
\hline & \multicolumn{4}{|c|}{ Turnout (Self-reported: 87\%) } & \multicolumn{4}{|c|}{$\begin{array}{l}\text { Turnout (Constructed } \\
\text { indicator: } 69 \% \text { ) }\end{array}$} \\
\hline & $\mathrm{B}$ & E.T. & Wald & Sig. & $\mathrm{B}$ & E.T. & Wald & Sig. \\
\hline \multicolumn{9}{|l|}{ Personality } \\
\hline Openness & -.03 & .02 & 2.38 & .123 & .00 & .01 & .00 & .986 \\
\hline Conscientiousness & .01 & .02 & .19 & .666 & .00 & .02 & .02 & .894 \\
\hline Extraversion & .04 & .01 & 6.49 & .011 & .03 & .01 & 8.01 & .005 \\
\hline Agreeableness & .02 & .02 & .53 & .467 & .00 & .02 & .00 & .976 \\
\hline EmotionalStability & .04 & .02 & 3.29 & .070 & .03 & .01 & 3.36 & .067 \\
\hline \multicolumn{9}{|l|}{ Demographics } \\
\hline Male & -.48 & .16 & 8.43 & .004 & -.08 & .12 & .49 & .486 \\
\hline Age & .02 & .01 & 11.90 & .001 & .00 & .00 & 1.15 & .283 \\
\hline Education & .03 & .02 & 1.70 & .192 & .00 & .01 & .00 & .970 \\
\hline \multicolumn{9}{|l|}{ Predispositions } \\
\hline Intensity of partyidentification & .22 & .11 & 3.86 & .050 & .47 & .08 & 33.95 & .000 \\
\hline Politicalengagementindex & .27 & .05 & 3.52 & .000 & .19 & .03 & 3.99 & .000 \\
\hline Religiosity & -.03 & .10 & .08 & .783 & -.06 & .07 & .63 & .426 \\
\hline Left & -.04 & .20 & .03 & .853 & .29 & .15 & 3.59 & .058 \\
\hline Right & .09 & .20 & .20 & .657 & .18 & .14 & 1.67 & .197 \\
\hline Constante & -1.38 & .57 & 5.80 & .016 & -1.42 & .42 & 11.56 & .001 \\
\hline \% Correctlypredicted & 87.2 & & & & 71.5 & & & \\
\hline \multicolumn{9}{|l|}{$\mathrm{R}$ squared } \\
\hline Cox\&Snell & .06 & & & & .08 & & & \\
\hline Nagelkerke & .11 & & & & .11 & & & \\
\hline
\end{tabular}

Levels of significance: ${ }^{*} \mathrm{p}<.05 ;{ }^{* *} \mathrm{p}<.01 ;{ }^{* * *} \mathrm{p}<.001$

Source: Comparative National Elections Project in the 2012 Mexican presidential election.

The analysis of our constructed variable of turnout confirms the significant and positive effects of extraversion. Noticeably, all demographic influences faded. In this case, political engagement maintains its importance but the influence of party 
identification actually increased substantially. Strong partisans were significantly more likely to vote and to report who they voted for. In the model of our constructed indicator of turnout, the dummy variable for Left also attained statistical significance, showing that leftist voters were actually slightly more likely to vote than the Right or than Centrist voters (who serve as reference along with those who did not place themselves on the scale).

These results clearly show that extraversion exerts a significant influence on turnout, and it does so regardless of the way turnout is empirically represented. This is, this result holds either when turnout is constructed with a simple self-reported measure (which largely overestimates the actual turnout figure), or when turnout is constructed with a more demanding measure that requires the respondent to disclose who she voted for in different political offices (president, senator, deputy). Extraverted individuals were more likely to participate in the election, or at least to report so.

To see this more graphically, Figure 1 shows the predicted probabilities of turnout (derived from the constructed indicator model), for each level of extraversion and controlling for the three levels of intensity of party identification. As we move from the introverted pole of the scale to the extraverted one, the probability of voting increases, regardless of the intensity of partisanship. Moreover, the most extraverted nonpartisans were as likely to turnout on the election as introverted weak partisans. Likewise, extraverted weak partisans were slightly more likely to vote than introverted strong partisans. Extraversion does in fact add important information to our understanding of who voted in the 2012 presidential election. 
Figure 1 - Predicted probabilities of turnout (constructed indicator), by personality and intensity of partisanship

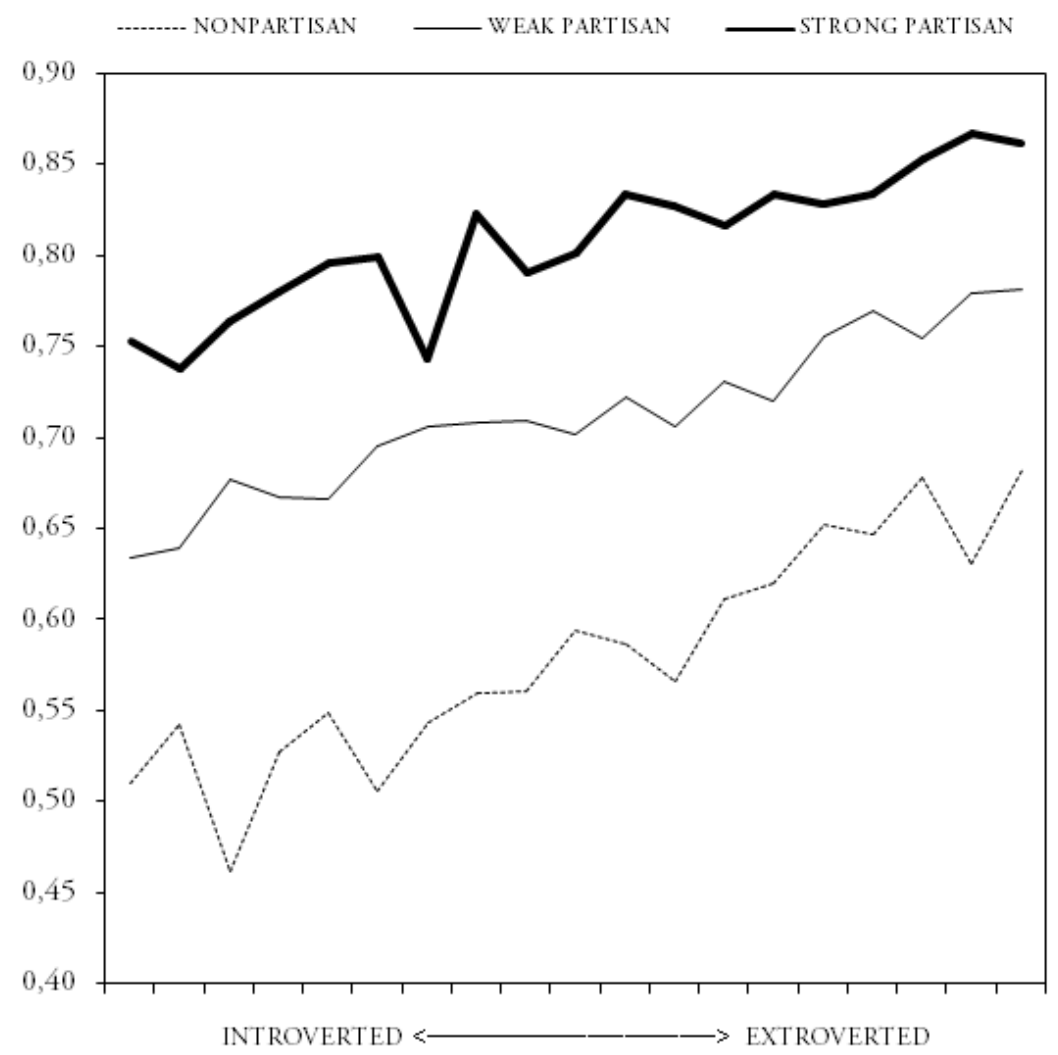

Source: Comparative National Elections Project in the 2012 Mexican presidential election.

But extraversion also adds to our understanding of who engaged in other forms of political participation, such as political discussion. Table 2 shows the results of the model for the different dependent variables accounting for a number of modes of political discussion. As can be seen, among the personality variables, both openness to experience and extraversion are the only variables with a positive effect across every dependent variable. The coefficient for extraversion, however, attains statistical significance in every one of them, whereas the coefficient for openness only does in the talk to family model. Interestingly, the coefficient for agreeableness is negatively signed in all but one of the political discussion models (convince others), but fails to attain statistical significance at the $\mathrm{p}<.05$ level under every specification. Conscientiousness does not exert a substantive influence on political engagement in the form of political discussion, but this result is not at odds with past research. 
Again, conscientious individuals may simply not deem the political arena anywhere near as important as performance in the workplace or family responsibilities.

Table 2 - A model of political discussion: The role of personality traits (OLS regression)

\begin{tabular}{|c|c|c|c|c|c|c|c|c|c|c|c|c|}
\hline & \multicolumn{2}{|c|}{$\begin{array}{c}\text { Convinceo- } \\
\text { thers } \\
(\mathrm{p} 4)\end{array}$} & \multicolumn{2}{|c|}{$\begin{array}{l}\text { Talk to family } \\
\text { (p42a) }\end{array}$} & \multicolumn{2}{|c|}{$\begin{array}{l}\text { Talk to } \\
\text { friends } \\
\text { (p42b) }\end{array}$} & \multicolumn{2}{|c|}{$\begin{array}{c}\text { Talk to } \\
\text { neighbors } \\
\text { (p42c) }\end{array}$} & \multicolumn{2}{|c|}{$\begin{array}{c}\text { Talk to } \\
\text { co-workers } \\
\text { (p42d) }\end{array}$} & \multicolumn{2}{|c|}{$\begin{array}{c}\text { Talk to others } \\
\text { (additive } \\
\text { index) }\end{array}$} \\
\hline & Beta & Sig. & Beta & Sig. & Beta & Sig. & Beta & Sig. & Beta & Sig. & Beta & Sig. \\
\hline \multicolumn{13}{|l|}{ Personality } \\
\hline Openness & .01 & .627 & .06 & .015 & .02 & .525 & .00 & .921 & .01 & .790 & .02 & .459 \\
\hline Conscientiousness & .00 & .905 & -.01 & .591 & .01 & .831 & .00 & .886 & -.01 & .714 & .00 & .919 \\
\hline Extraversion & .05 & .047 & .11 & .000 & .14 & .000 & .13 & .000 & .10 & .000 & .15 & .000 \\
\hline Agreeableness & .02 & .450 & -.05 & .058 & -.04 & .182 & -.02 & .557 & -.05 & .056 & -.05 & .076 \\
\hline EmotionalStability & -.02 & .367 & .01 & .696 & -.01 & .787 & .02 & .416 & .03 & .244 & .01 & .570 \\
\hline \multicolumn{13}{|l|}{ Demographics } \\
\hline Male & .07 & .003 & .01 & .801 & .13 & .000 & .00 & .901 & .27 & .000 & .15 & .000 \\
\hline Age & -.04 & .080 & -.04 & .102 & -.04 & .121 & .02 & .431 & -.06 & .038 & -.03 & .215 \\
\hline Education & .12 & .000 & .13 & .000 & .17 & .000 & -.02 & .405 & .17 & .000 & .15 & .000 \\
\hline \multicolumn{13}{|l|}{ Predispositions } \\
\hline Party id. intensity & .09 & .000 & .13 & .000 & .09 & .000 & .12 & .000 & .06 & .020 & .12 & .000 \\
\hline $\begin{array}{c}\text { Political } \\
\text { engagement }\end{array}$ & .40 & .000 & .30 & .000 & .27 & .000 & .20 & .000 & .19 & .000 & .30 & .000 \\
\hline Religiosity & .03 & .185 & .06 & .009 & .05 & .052 & .08 & .002 & .05 & .060 & .08 & .001 \\
\hline Left & .05 & .058 & .09 & .000 & .10 & .000 & .07 & .012 & .07 & .013 & .10 & .000 \\
\hline Right & .03 & .240 & .04 & .198 & -.01 & .796 & .03 & .246 & .04 & .139 & .03 & .291 \\
\hline Constant & & .001 & & .000 & & .001 & & .019 & & .056 & & .000 \\
\hline $\begin{array}{c}\text { Adjusted R } \\
\text { squared }\end{array}$ & .23 & & .20 & & .20 & & .10 & & .19 & & .24 & \\
\hline
\end{tabular}

Levels of significance: ${ }^{*} \mathrm{p}<.05 ;{ }^{* *} \mathrm{p}<.01 ;{ }^{* * *} \mathrm{p}<.001$

Source: Comparative National Elections Project in the 2012 Mexican presidential election.

Regarding our controls, as expected, our index of political engagement (interest in politics and in the campaigns) has a systematically significant and positive effect in all variables of political discussion, being one of the most consistent predictors of people's conversation about politics with family, friends, neighbors, and co-workers, as well as attempts of persuasion. The intensity of party identification is also rather consistent, though it exerts a modest effect in talking with co-workers. The results also show voters on the Left generally more likely to engage in political 
discussions than voters on the Right. And religiosity also relates positively to talking about the campaigns but exerts a modest influence in attempts of persuasion.

The demographic variables show that men are more likely to discuss politics than women except in realms of family and neighbors, where no significant differences are observed by gender. Men are also more likely than women to try to convince others of their political views. Age shows null effects or very modest ones: younger voters were slightly more likely to talk about politics with co-workers. Education is a more or less consistent predictor of political discussion and persuasion, but it fails to contribute to discussion with neighbors.

Our last test focuses on views about the political process, especially on the acceptance or rejection of electoral malpractices, such as obstruction of campaign activities and the use of violence for political goals. Table 3 shows the results for the same explanatory model using now those views as dependent variables. As shown, age and education have a negative relationship with both views, which means that older voters and more educated ones are more likely to reject obstructive practices and violent means. Sex shows no significant effect. None of the political predispositions exert a significant influence in these views either, except for the Left category, which has a modest but positive effect on obstruction. That is, leftist voters are slightly more likely to accept the obstruction of campaign activities, which probably reflect phenomena of civil disobedience observed in Mexico after the leftist presidential candidate lost the elections of 2006 and 2012. 
Table 3 - A model of political views towards electoral integrity: The role of personality traits. (OLS regression)

\begin{tabular}{|c|c|c|c|c|}
\hline & \multicolumn{2}{|c|}{ Obstruction (p98a) } & \multicolumn{2}{|c|}{ Violence (p98b) } \\
\hline & Beta & Sig. & Beta & Sig. \\
\hline \multicolumn{5}{|l|}{ Personality } \\
\hline Openness & 0.06 & 0.035 & 0.11 & 0.000 \\
\hline Conscientiousness & -0.05 & 0.095 & 0.00 & 0.908 \\
\hline Extraversion & -0.04 & 0.150 & -0.06 & 0.029 \\
\hline Agreeableness & 0.01 & 0.769 & -0.06 & 0.042 \\
\hline EmotionalStability & 0.03 & 0.305 & -0.01 & 0.698 \\
\hline \multicolumn{5}{|l|}{ Demographics } \\
\hline Male & -0.05 & 0.075 & -0.03 & 0.325 \\
\hline Age & -0.10 & 0.000 & -0.10 & 0.001 \\
\hline Education & -0.10 & 0.001 & -0.11 & 0.000 \\
\hline \multicolumn{5}{|l|}{ Predispositions } \\
\hline Party id. intensity & -0.02 & 0.453 & 0.02 & 0.400 \\
\hline Pol. engagement & 0.02 & 0.440 & -0.01 & 0.763 \\
\hline Religiosity & 0.00 & 0.986 & 0.05 & 0.068 \\
\hline Left & 0.07 & 0.011 & 0.03 & 0.225 \\
\hline Right & 0.04 & 0.162 & 0.02 & 0.522 \\
\hline Constant & & 0.000 & & 0.000 \\
\hline Adjusted R squared & 0.02 & & 0.03 & \\
\hline
\end{tabular}

Levels of significance: ${ }^{*} \mathrm{p}<.05 ;{ }^{* *} \mathrm{p}<.01 ;{ }^{* * *} \mathrm{p}<.001$

Source: Comparative National Elections Project in the 2012 Mexican presidential election.

Among the personality traits, openness seems to have a significant effect on these two political views: a modest effect on obstruction and a much more significant effect on the use of violence. In both cases, the coefficient for openness is positively signed suggesting that higher levels of openness were more conducive of acceptance of electoral malpractices, at least during the aftermath of the 2012 presidential election in Mexico. Neither conscientiousness nor emotional stability seems to make any difference in the acceptance of these political views. By contrast, extraversion exerts a significant and negative effect on the acceptance of violence, as also does agreeableness. These two personality traits hinder the justification of violent means to alter the outcome of a democratic election. If we add the fact that extraversion also boosts political participation, we may be looking at a significant personality factor that, at least in Mexico, seems to heighten the prospects of individual-level engagement in highly desirable practices and principles of democracy in a context where such practices and principles are not yet the law of the land. 


\section{Conclusions}

Political scientists have devoted scores of scholarly work to understanding the causes of political behavior. Developments in the field of psychology regarding the measurement of personality utilizing the Big Five approach have given rise to a burgeoning line of research in political science focusing on the effects of personality traits on political attitudes and behavior. This line of research has called our attention to the fact that traditional models of political behavior can only yield an incomplete portrait of the origins of political participation. As Mondak and colleagues argue, exploring the political consequences of the Big Five personality trait dimensions moving "beyond advanced democracies is an essential step in ascertaining whether the impact of personality reaches across contexts and cultures" (MONDAK et al., 2011, p. 212). Our study joins this emerging line of scholarly work by exploring the effects of personality traits on the formation of political views and the propensity to adopt certain political behaviors in the context of a new democracy: Mexico in the aftermath of this country's most recent presidential election. To the best of our knowledge, our study is a pioneering effort testing the political consequences of personality in Mexico.

In general, our findings provide further supporting evidence that, along with traditional demographic and political factors, enduring psychological differences lie at the origin of political beliefs, attitudes, and behaviors. We believe that incorporating measures of personality traits into our models of political behavior enhances our understanding of who participates in politics and why. Specifically, some of our findings run counter to the extant literature and warrant at least a final comment and certainly further research and consideration.

In our analyses, extraversion (and not openness to experience) is the most influential personality trait accounting for the individual propensity to turnout in this election. Of course, this finding would require replication before any definitive conclusions can be made regarding this relationship in contexts with similar political conditions of those observed in Mexico in recent years. Extraversion also fosters political discussion with family members, friends, neighbors, and co-workers, and heightens the propensity that individuals will take action by trying to convince others of the advantages of their own political preferences.

Interestingly, extraversion fosters outreach efforts that encompass convincing others of one's own political beliefs, however, extraversion also decreases the likelihood that an individual will display support for obstruction of campaign acts or for the use of violence to alter the outcome of a democratic election. Because of these findings altogether, we believe extraversion possesses the greatest potential to 
influence mass politics in contexts where democracy is relatively new and the development of democratic principles and practices among the public resembles a house still under construction.

Finally, we uncover a potentially troublesome relationship between openness to experience and support for political violence to alter the course and outcomes of electoral campaigns. Past research has shown that openness to experience is positively related with different forms of civic engagement. Our results do not match that pattern. If our finding, though, were to be replicated in Mexico and other settings, a question arises. Under what conditions openness leads to an authoritarian rather than to a participatory personality? In other words, under what conditions, openness leads to enhanced prospects of consolidation of new democracies by encouraging highly desirable behaviors such as turnout, and under what circumstances openness may trigger support for political violence to alter the outcomes of democratic elections? Mexico, like other new democracies, offers an ideal setting to continue finding answers to this puzzle, which may not have had an opportunity to develop in more stable political contexts lacking a recent institutional history of authoritarianism. Of course, we acknowledge that our study is only an initial step, and that more work needs to be done. It is our sincere hope, however, that our findings will become part of the multiplying building blocks in the literature of personality and political behavior.

Alejandro Moreno é Professor do Departamento de Ciência Política do Instituto Tecnológico Autônomo do México. E-mail: amoreno@itam.mx

- Sergio C. Wals é Professor Assistente do Departamento de Ciência Política e Instituto de Estudos Étnicos da Universidade de Nebrasca. E-mail: swals2@unl.edu

\section{References}

ADORNO, Theodor W. The Authoritarian Personality. New York: Harper, 1950.

CHURCH, Timothy. Culture and Personality: Toward an Integrated Cultural Trait Psychology. Journal of Personality, v. 68, n. 4, p. 651-703, 2001. 
CONNOLLY, James; KAVANAGH, Erin; VISWESVARAN, Chockalingam. The Convergent Validity between Self and Observer Ratings of Personality: A Meta-Analytic Review. International Journal of Selection and Assessment, v. 15, n. 1, p. 110-117, 2007.

DENNY, Kevin; DOYLE, Orla. Political Interest, Cognitive Ability and Personality:

Determinants of Voter Turnout in Britain. British Journal of Political Science, n. 38, p. 291-310, 2008.

GERBER, Alan et al. Personality Traits and Participation in the Political Processes. The Journal of Politics, v. 73, n. 3, p. 692-706, 2011.

. Personality and Political Attitudes: Relationships across Issue Domains and Political Contexts. American Political Science Review, v. 104, n. 1, p. 111-133, 2010.

GOLDBERG, Lewis. An Alternative Description of Personality: The Big Five Factor Structure. Journal of Personality and Social Psychology, v. 59, n. 3, p. 1216-1229, 1990.

GOSLING, Samuel; RENTFROW, Peter; SWANN, William. A Very Brief Measure of the Big-Five Personality Domains. Journal of Research in Personality, v. 37, p. 504-528, 2003.

MCCRAE, Robert; COSTA, Paul. Personality in Adulthood: A Five-Factor Theory Perspective. New York: Guilford, 2003.

. Personality Trait Structure as a Human Universal. American Psychologist, v. 52, n. 5, p. 509516, 1997.

MONDAK, Jeffery. Personality and the Foundations of Political Behavior. New York: Cambridge University Press, 2010.

MONDAK, Jeffery et al. Personality and Civic Engagement: An Integrative Framework for the Study of Trait Effects on Political Behavior. American Political Science Review, v. 104, n. 1, p. 85-110, 2010 .

. The Participatory Personality: Evidence from Latin America. British Journal of Political Science, v. 41, n. 1, p. 211-221, 2011.

MONDAK, Jeffery; HALPERIN, Karen. A Framework for the Study of Personality and Political Behaviour. British Journal of Political Science, v. 38, n. 2, p. 335-362, 2008.

MORENO, Alejandro. El Votante Mexicano. Ciudad do México: Fondo de Cultura Económica, 2003.

MORENO, Alejandro. La decisión electoral: Votantes, partidos y democracia en México. Ciudad do México: H. Cámara de Diputados y Miguel Ángel Porrúa, 2009.

MUSSEN, Paul H.; WYSZYNSKI, Anne B. Personality and Political Participation. Human Relations, v. 5, p. 65-82, 1952.

SNIDERMAN, Paul. Personality and Democratic Politics. Berkeley: University of California Press, 1975.

VECCHIONE, Michele; CAPRARA, Gian. Personality Determinants of Political Participation: The Contribution of Traits and Self-Efficacy Beliefs. Personality and Individual Differences, v. 46, n. 4, p. 487-492, 2009.

Texto recebido em 17 de dezembro 2013. Aprovado em 25 de março de 2014. 
